\title{
正20面体クラスターをもつ ボロン系半導体の熱電特性
}

\author{
中山高博*十 木村 薰*,** \\ *東京大学大学院工学系研究科材料学専攻 \\ **東京大学大学院新領域創成科学研究科物質系専攻
}

J. Japan Inst. Metals, Vol. 63, No. 11 (1999), pp. 1400-1406

Special Issue on Thermoelectric Energy Conversion Materials

\section{Thermoelectric Properties of Boron-Rich Icosahedral Cluster Semiconductors}

\author{
Takahiro Nakayama*† and Kaoru Kimura*,** \\ *Department of Materials Science, The University of Tokyo, Tokyo 113-8656 \\ **Department of Advanced Materials Science, The University of Tokyo, Tokyo 113-8656
}

\begin{abstract}
$\beta$-rhombohedral boron ( $\beta$-boron) is expected to be one of the candidates for high-temperature thermoelectric materials because of its hopping conduction mechanism. To reveal the controllability of the thermoelectric properties of boron-rich semiconductors which consisted mainly of $\mathrm{B}_{12}$ icosahedral clusters, $\beta$-boron was doped with $\mathrm{V}, \mathrm{Cr}, \mathrm{Fe}, \mathrm{Co}$ or $\mathrm{Zr}$, and the composition and temperature dependence of the electrical conductivity and the Seebeck coefficient were investigated. $\mathrm{V}$ or $\mathrm{Cr}$ dopant which preferentially occupies the $\mathrm{A}_{1}$ sites in $\beta$-boron structure causes an increase of the electrical conductivity and a negative Seebeck coefficient. On the other hand, $\mathrm{Zr}$ dopant which does not occupy the $\mathrm{A}_{1}$ sites causes a large positive Seebeck coefficient. The electrical conductivity and Seebeck coefficient of $\mathrm{Co}$ - and $\mathrm{Zr}$-doubly-doped p-type $\beta$-boron are nearly determined by the Co content. These results have been discussed with the concept of metallic-covalent bonding conversion for the $B_{12}$ cluster. The temperature dependence of the electrical conductivity of metal-doped $\beta$-boron is well explained as the variable range hopping conduction. The Seebeck coefficient as well as the electrical conductivity increases with increasing temperatures up to room temperature, contrary to the cases of ordinary metals and semiconductors. Consequently, the power factors of both $\mathrm{Co}$-doped $\mathrm{p}$-type $\beta$-boron and $\mathrm{V}$ - or $\mathrm{Cr}$-doped $\mathrm{n}$-type $\beta$-boron increase with increasing temperature, and materials whose power factor is $3-4$ orders of magnitude larger than that of pure $\beta$-boron at room temperature were obtained by doping with about 1 at $\%$ metal atoms.
\end{abstract}

(Received May 10, 1999; In Final Form September 16, 1999)

Keywords: $\beta$-rhombohedral boron, metal doping, electrical conductivity, Seebeck coefficient, site occupancy, hopping conduction, power factor

\section{I，序論}

1960年代に開始された半導体熱電発電の研究は, Ioffe $の$ 指導原理 (1) 基ついて, 移動度と有効質量の大きい材料につ いて行われた. Ioffe の指導原理はボルッマンの輸送方程式 走緩和時間近似して導出されて括り(1)-(3), 電気伝導率 $(\sigma)$, ゼーベック係数 $(S)$ 就よびキャリアの熱伝導率 $\left(\kappa_{\mathrm{el}}\right)$ はキャリ ア濃度のみで一意的に定まってしまら，そのため，実用材料 として十分な特性を得るにはいたっていない，乙かて，電子

†東京大学大学院生, 日本学術振興会特別研究員, 現在: 東京大 学博士研究員, 日本学術振興会特別研究員 (Graduate Student and Research Fellow of Japan Society for the Promotion of Science, The University of Tokyo, Present address: Postdoctoral Research Fellow of Japan Society for the Promotion of Science, The University of Tokyo)
相関や電子-格子相互作用が強い系では，この指導原理によ って熱電特性を説明できない場合が生じる．最近になって， ボロン系や酸化物系などの移動度の小さい材料も高温で高い 性能を示すことが報告され(4), 高温熱電変換材料として注目 されるよらになってきて扣り，新たな材料探索指針の存在が 示唆される。

ボロン系半導体は，価電子不足のために三中心共有結合を 有する $\mathrm{B}_{12}$ 正 20 面体クラスタ一から構成され，クラスタ一 内外の強固な結合 (5)を反映して，2300 K 以上の高い融点を 持つ，その輸送特性は電子一格子相互作用によるキャリアの 局在を示すホッピング伀導型であり，3 族の元素であるボ口 ンを主成分としながらも金属的な電気伝導率は示さず， $\mathrm{p}$ 型 の半導体となっている。これは $\mathrm{B}_{12}$ 正20面体クラスターが Jahn-Teller 効果によって䨤み, 固体の価電子带直上に内因 性のアクセプタ準位が形成され，フェルミ準位がこの離散的 
な局在準位以位置するためと考えられている(6)，バンド质導 を示寸通常の金属や半導体では， $\sigma$ が増大するとSが減少 乙, 出力因子 $\left(P=S^{2} \sigma\right)$ はキャリア濃度や温度に対して極大 を持つ. ところがホッピング伝導では温度の增加とともに $\sigma$ も $S$ む増加し, 高温になる汪どPが大きくなる(7)。また正 20 面体クラスターが結晶の並進対称性とは相容れない 5 回 対称性を持つために, 柆ロン系半導体中の $\mathrm{B}_{12}$ クラスターの ネットワークは複雑で, その結晶構造は隙間の多い大きな単 位胞をすつものが多く, 格子の熱伝導率 $\left(\kappa_{\mathrm{ph}}\right)$ 子小さい，ボ ロン系正20面体クラスター半導体には 9 種の結晶構造とア モルファス構造が存在し，その中でる $\beta$ ボロン(8)，金属ド 一ピングした $\beta$ ボロン(9), $\alpha-\mathrm{AlB}_{12}{ }^{(8)}, \mathrm{B}_{x} \mathrm{C}(4 \leq x \leq 10)^{(7)}$, $\mathrm{B}_{14} \mathrm{Si}^{(10)(11)}$ は大きなゼ一ベック係数を持つことで知られ， $800 \mathrm{~K}$ 以上の高温で動作する $\mathrm{p}$ 型の熱電半導体として期待 さ机ている。

筆者らは，電子-格子相互作用の強いボロン系正20面体ク ラスタ一半導体に打いて，個々のクラスターとその配列を制 御・設計することによって固体の電子状熊を制御し, 熱電特 性向上の可能性を検討している. 従来の材料比和いてる，た とえば，半導体相である $\beta-\mathrm{FeSi}_{2}$ と金属相である $\varepsilon-\mathrm{FeSi}_{2}$ の

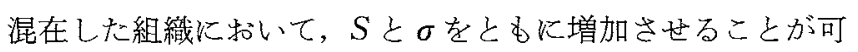
能であることが報告されている(12)． $\mathrm{B}_{12}$ クラスタ一は柾.2 で詳しく述べるように，クラスター内外の状況の変化によ り，共有結合をとったり，金属結合をとったりする(13)-(15). 一つの材料の中に, 金属結合的な部分と共有結合的な部分を 局所的に混在さ好, 金属的飞高い電気伝導率々半導体的に高 いゼーベック係数を併せ持った材料が創製できるならば，熱 電特性の更なる向上に大きく貢献する。そこで，電子-格子 相互作用の強い系での熱電材料探索指針を確立することを目 指し, 本研究では, $\beta$ 菱面体晶ボロンの異なる 3 種のサイト に金属を選択的にドーピングすることによって， 電気伝導率とゼーヘッッ係数の制御機構 $(\mathrm{p}$ 型, $\mathrm{n}$ 型を作り 分ける方法と, 電気伝導率和よびゼーベック係数を独立化制 御する方法も含む)を解明することを目的として実駼を行っ た.

\section{II. 実 験 方 法}

アモルファス・ボロン(純度 $99.9 \%$ ) 柇よび金属 $(\mathrm{V}, \mathrm{Cr}, \mathrm{Fe}$, Co, $\mathrm{Zr}$ : 純度 $99.9 \%$ )の調合粉末を $\mathrm{Ar}$ 雾囲気中でアーク溶 解することによって，金属をドーピングした $\beta$ 菱面体晶ボ ロン試料を作製した，引き続き $\mathrm{h}-\mathrm{BN}$ るつ绿に入れ， $\mathrm{Ar}$ 霖 囲気中で $2073 \mathrm{~K}-48 \mathrm{~h}$ の熱処理を施して均質化を行った。過 㮃な金属は塩酸で除去した。これらの試料の一部を粉碎し て, 粉末 X線回折測定を行った。 引き続き, Rietveld 法に よる粉末 X 線構造解析を行って, 格子定数とドーピング . サイトの占有率を求めた。粉末 $\mathrm{X}$ 線回折測定は, 粉碎した 試料を秼理学電機製の $\mathrm{SiO}_{2}$ 単結晶からなる無反射試料板に マウントし， $\mathrm{Cu} \mathrm{K} \mathrm{K}_{\alpha}$ 線を用いて，むず $10^{\circ}$ から $80^{\circ}$ の範用で測
定を行った．次に内部標準試料として Si 粉末を混合して Si のピークを含む限られた範囲 $\left(37^{\circ}\right.$ から $\left.57^{\circ}\right)$ で精密測定を行っ た. Rietveld 解析ではプログラムRIETAN-97 $\beta^{(16)}$ 用い て, これら 2 種類のX 線回折データを使って格子定数とド ーピング・サイトに款けるドーパントの占有率を求めた，構 造ハララメータは単結晶の構造解析 $\mathrm{VB}_{65}{ }^{(17)}, \mathrm{CrB}_{41}{ }^{(18)}$, $\mathrm{FeB}_{49}{ }^{(19)}, \mathrm{Zr}_{51}{ }^{(20)}$ 加ら求まっている值を初期值とし, Co r ーピングに関しては， $\mathrm{FeB}_{49}$ 構造を初期值とした． 3 種のド ーピングサイト $\mathrm{A}_{1}, \mathrm{D}, \mathrm{E}$ を仮定して解析を行い, 解析の途 中で占有率が 0 以下になるサイトは，削除して引き続き解 析を行った，内部座標は格子定数の变化による若干の修正の

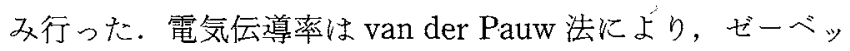
ク保数は定常温度差法によって, 温度依存性㧍よび組成依存 性を室温以下で調べた。

\section{III. 実験結果と考察}

\section{1. 粉末 X 線構造解析}

Fig. 1 亿純ボロンの高温の安定相である $\beta$ 菱面体晶ボロ ン $\left(\beta\right.$ ボロン: $\left.\mathrm{B}_{105}\right)$ の結晶構造を示す。 $\beta$ ボロンは $\mathrm{B}_{12}$. $3\left(\mathrm{~B}_{12}\right) \cdot\left(-\mathrm{B}_{28}-\mathrm{B}-\mathrm{B}_{28}\right)$ と表せ, vertex と edge center の 2 種 類の $\mathrm{B}_{12}$ クラスターからなる菱面体晶と，その体対角線に $\mathrm{B}_{28}$ 二ニット怙よび単独 B 原子からなるチェーンを配置した 構造であり，単位胞に105個のB原子を含む(21)。この構造 は見方を变光ると $\mathrm{B}_{84} \cdot\left(-\mathrm{B}_{10}-\mathrm{B}-\mathrm{B}_{10}\right)$ とも表せ， $\mathrm{B}_{84}$ クラスタ 一第三殼が $\mathrm{B}_{60}$ サッカーボール・クラスターであり，第一 殸と第二殼に $\mathrm{B}_{12}$ 正20面体クラスターを二重に入礼子に たクラスターである(22)。これらのクラスターの隙間には 3 種の主要なドーピング・サイト $\mathrm{A}_{1}, \mathrm{D}, \mathrm{E}$ が知られて乱り, 遷移金属原子などを収容するのに十分な大きさを持っ(23).

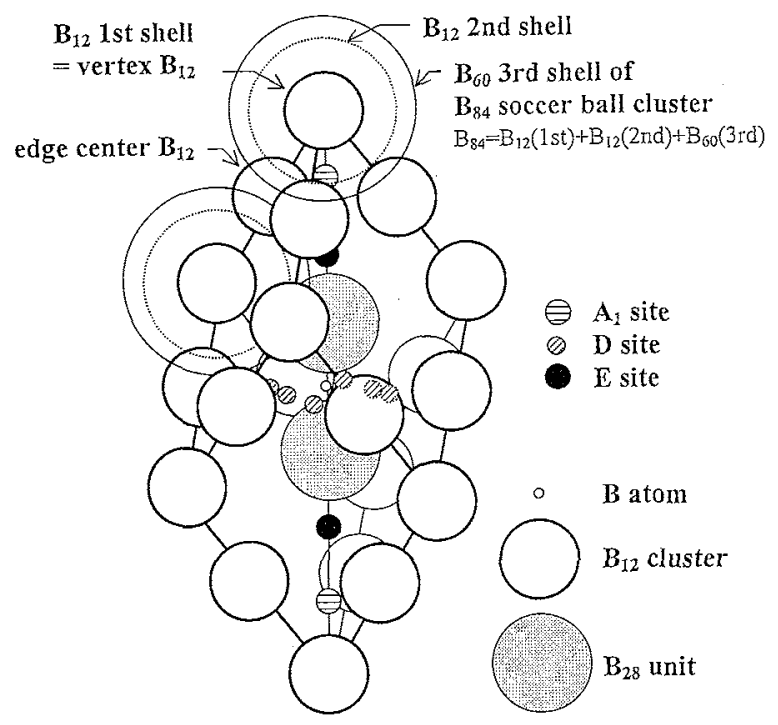

Fig. $1 \beta$-rhombohedral boron structure and three kinds of interstitial doping sites. 
$\mathrm{B}_{84}$ サッカーボール・クラスター内部には第 2 殼付近に正 12 面体を形成する $\mathrm{A}$ サイト $\left(=2 \mathrm{~A}_{1}+12 \mathrm{~A}_{2}+6 \mathrm{~A}_{3}\right)$ が存在し， $\mathrm{B}_{12}$ 正20面体第 2 殼と之もに菱形30面体を形成するサイトで ある、 $\mathrm{A}_{1}$ サイトは1つの vertex $\mathrm{B}_{12}$ と 3 つの edge center $\mathrm{B}_{12}$ に囲李れた四面体空隙に存在する。 D サイトは体対庙線 の - $\mathrm{B}_{10}-\mathrm{B}-\mathrm{B}_{10}$ チェーンの周囲に，Eサイトは 4 つの $\mathrm{B}_{84}$ サッ カーボール・クラスターに囲まれる四面体空陌に存在する.

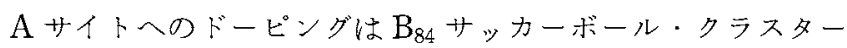
内部の第 2 款へのドーピングに， $\mathrm{E}$ サイトは $\mathrm{B}_{84}$ クラスター 間へのドーピングに対応する。

作製された $\mathrm{M}_{x} \mathrm{~B}_{105}(\mathrm{M}=\mathrm{V}, \mathrm{Cr}, \mathrm{Fe}, \mathrm{Co}, \mathrm{Zr})$ 試料について, Rietveld 法を用いた粉末 X 線構造解析によって構造パラメ 一夕を精密化した結果，それぞれの試料に対して単位胞体積 の増加が見ら礼， $x \leq 1$ ではすべて金属が侵入型にドープさ れた $\beta$ 菱面体晶禾ロン単相である。市た， Rietveld 解析沶 よび SEM 観察より， $\mathrm{Cr}_{x} \mathrm{~B}_{105}$ の $x \geq 1.5$ では 2 種類の $\mathrm{Cr}-\mathrm{B}$ 化合物の共晶組織が微量に分散していることが確認され た(24)、ドーピング・サイトの占有率の精密化の結果，Vと $\mathrm{Cr}$ は $\mathrm{A}_{1}$ サイトの占有率が高く，Fe と Co は $\mathrm{A}_{1}$ サイトと D サイトを同程度に占有するが，Zrは $\mathrm{A} \mathrm{A}_{1}$ サイトを占有しな い(24)。これらは単結晶 $\mathrm{VB}_{65}{ }^{(17)}, \mathrm{CrB}_{41}{ }^{(18)}, \mathrm{FeB}_{49}{ }^{(19)}$, $\mathrm{ZrB}_{51}(20)$ の構造解析から求まっている占有傾问と一致する.

2 節で述べる金属結合-共有結合転換を検証するため に，軌道放射光を使った粉末 X 線回折の精密測定を行い， Rietveld 法と最大エントロピー法を組み合せた解析手法に より,ドーピング前後での $\mathrm{B}_{12}$ もしくは $\mathrm{B}_{84}$ クラスターの電 子密度分布の変化を調べている。これらのクラスターが局所 的以共有結合から金属結合へと変化して行く様子を観察する 試みを行っているところである。

\section{2. 電気伝導率とゼーベック係数の組成依存性}

$\mathrm{A}_{1}$ サイトを占有する $\mathrm{V}, \mathrm{Cr}, \mathrm{Fe}, \mathrm{Co}$ のドーピングによっ

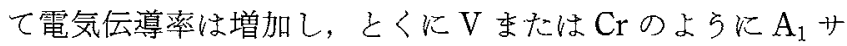
イトを高く占有する元素では著しく増加する(22)(25)(26).

Fig. 2 にCr ドーピングの場合の電気后導率 $(\sigma)$ ，ゼーベッ ク係数 $(S)$ 特よびドーピソグ・サイトの占有率の Cr 濃度依

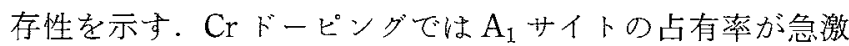
に上昇する組成 $(x \leq 1.0)$ で $\sigma$ が 5 桁以上増加する。逆に $\mathrm{A}_{1}$ サイトを占有しないZ Zrでは $\sigma$ の上昇はわずかである(Fig. 4, 5 参照)。また， $\mathrm{A}_{1}$ サイトを占有するドーパントでは $S$ が 減少し，とくにVと $\mathrm{Cr}$ ではn型を表す負の $S$ 示す。 $\mathrm{A}_{1}$

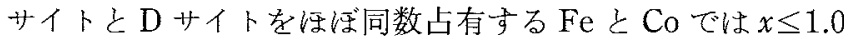
で $\mathrm{p}$ 型のままである。一方， $\mathrm{A}_{1}$ サイトを占有せず，D， Eサ イトのみを占有する $\mathrm{Zr}$ では，ドーピングによって $\mathrm{p}$ 型で $\beta$ ボロンより死大きな $S$ を示す(Fig. 4, 6 参照).

$\beta$ ボロン, $\mathrm{V} ト ゙ ー フ ゚ ・ \beta$ ボロン括よび $\mathrm{Zr}$ と同様の占有傾

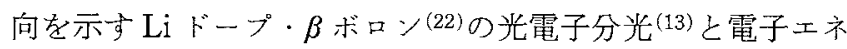

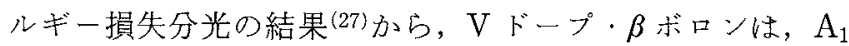
サイトを占有するVとボロンとの混成によってバンド・ギ

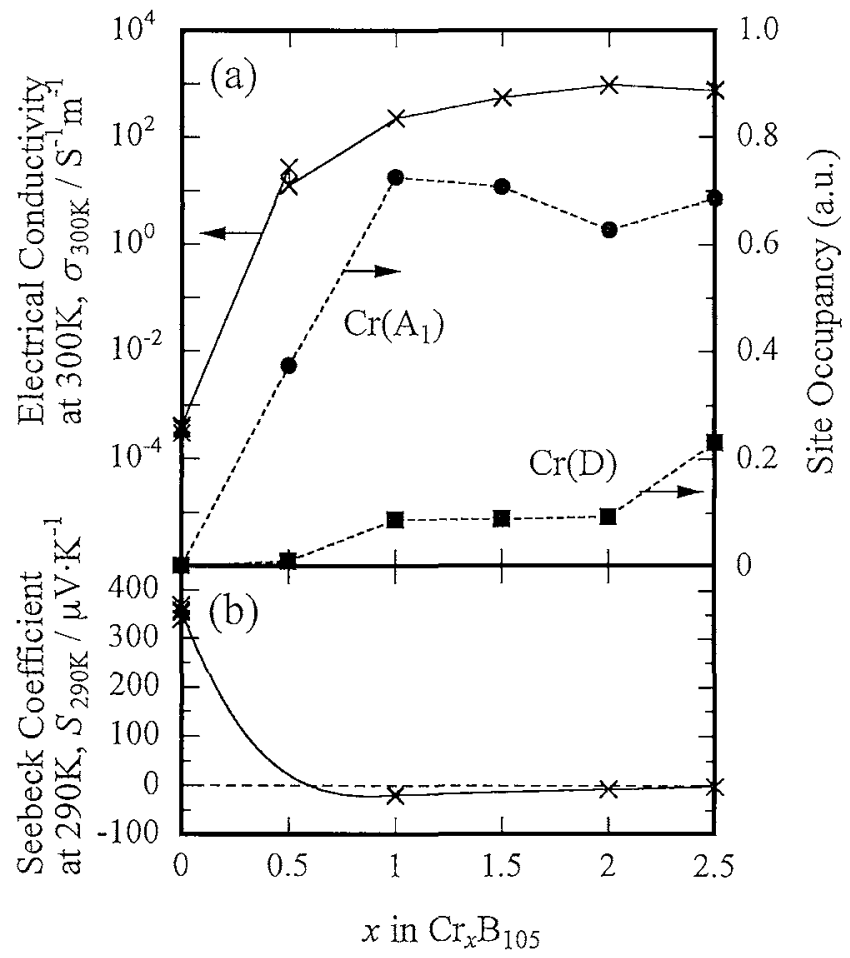

Fig. $2 \mathrm{Cr}$ concentration dependence of electrical properties and site occupancies for $\mathrm{Cr}$-doped $\beta$-rhombohedral boron. (a) The electrical conductivity at $300 \mathrm{~K}$ and the occupancies of the doping sites, and (b) the Seebeck coefficient at $290 \mathrm{~K}$.

ヤップが減少するとともに，フェルミ・エネルギーに括ける

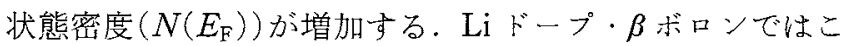
の効果は観測されない， $\mathrm{A}_{1}$ サイトはほぼ等距離にある12個 のB原子に囲まれているが，これと同様に12個のボロン原 子で囲李れた正20面体クラスターの中心では，原子の有無 により金属結合-共有結合転換が起こる(14)(15)ので， $\mathrm{A}_{1}$ サイ トの占有による混成は共有結合から金属結合への転換を示唆 している(13). VやCrのドーピングによるのの増加は，こ のよらな金属結合K転換した局所領域がドープ量とともに増 加するためであると考充られる。また，Sが負に転移するこ

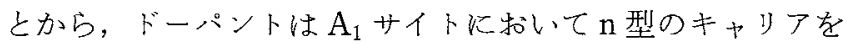
生成していると考党られる。一方，D，Eサイトを占有する Zrは，p型のまま $\sigma$ をわずかに増加させる，Zrドーピング の場合は Li ドーピング(22) と同様に， $\sigma$ の増加が小さく， $N\left(E_{\mathrm{F}}\right)$ はある増加しないことから，ハシンド端付近ではボ ロンと混成軌道を形成しないと考えられる。亦た通常の半導 体にキャリアをドープてて $\sigma$ が増加する場合と異なり，Sも 増加させる．ホッピング伝導に起因寸ると考穴られるこの效 果の原因はまだ十分解明さ礼ていないが，クラスター間への 侵入型ドーピングによる格子の膨張やクラスターの歪などが エネルギー状態密度分布を変えるためではないかと考党，ド ーピングによるパンド構造の変化を調査中である.

$\mathrm{A}_{1}$ サイトと $\mathrm{D}$ サイトを占有する原子数比を変古るために, $\mathrm{Cr}$ とeをダブル・ドーピングした $\beta$ ボロン $\mathrm{Cr}_{x} \mathrm{Fe}_{1-x} \mathrm{~B}_{105}$ 


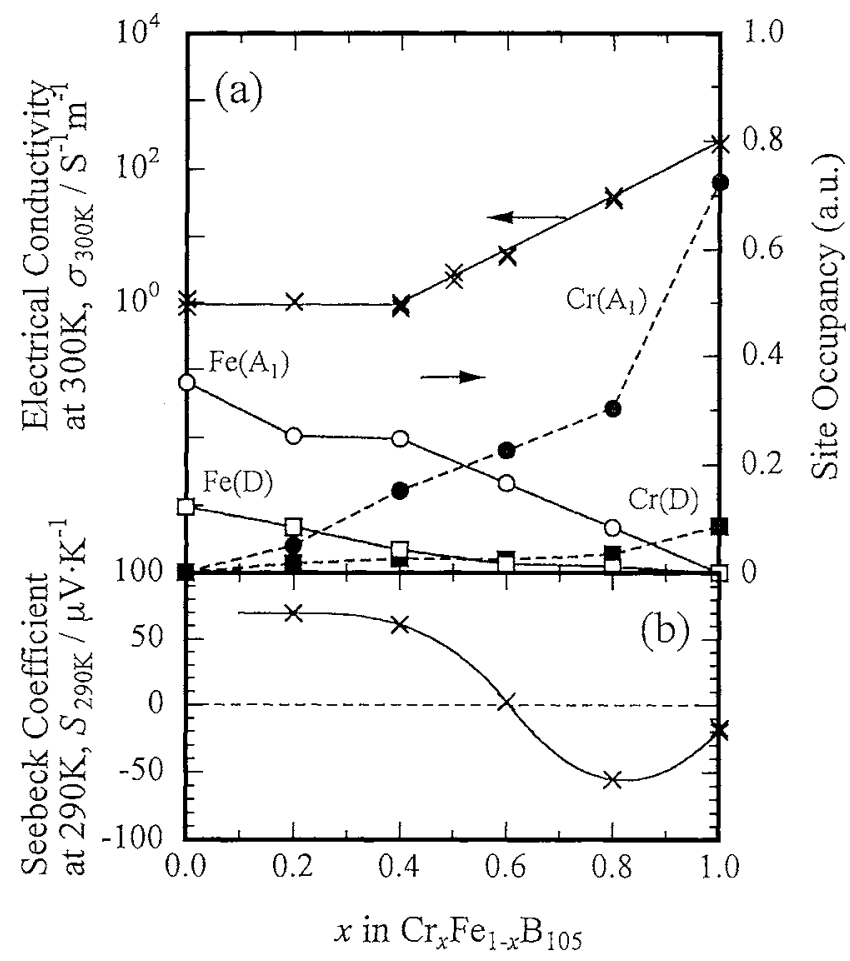

Fig. $3 \mathrm{Cr}$ concentration dependence of electrical properties and site occupancies for $\mathrm{Cr}$ - and $\mathrm{Fe}$-doubly-doped $\beta$-rhombohedral boron. (a) The electrical conductivity at $300 \mathrm{~K}$ and the occupancies of the doping sites, and (b) the Seebeck coefficient at $290 \mathrm{~K}$.

試料を作製した。 $\sigma$ Ｓ执よびドーピング・サイトの占有率 の組成依存性を Fig. 3 飞示吉. $x<0.5$ では電気伝導率はは 隹不変であるが，x>0.5で $\mathrm{A}_{1}$ サイトを占有する原子の数が $\mathrm{D}$ サイトよりも多くなると $\sigma$ が上昇し， $S$ が正から負に転

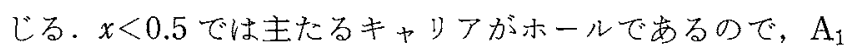
サイトを占有したC Crの゙ナーによって補償され，xの増加 とともに $\sigma$ が減少するはずである。しかし，Fig. 3 の結果 では，。は不変であり，補償の効果が観測されない， $\mathrm{A}_{1}$ サ イトを占有する $\mathrm{Cr}$ と $\mathrm{Fe}$ がボロンと混成することによって， バンド・ギャップを減少させるために，局在性の強い $\mathrm{p}, \mathrm{n}$ 双方のキャリアが伀導に寄与しているものと考えられる. ᄂ たがって，Dサイトは $\mathrm{p}$ 型のキャリアを生成している可能 性もある。

$\mathrm{Zr}$ ドーピングによって電気伝導率を低下させることなく ゼーベック係数を增加させることがでさるので，電気伀導率 とゼーベック係数を独立に制御できる可能性を示唆してい る. Coと Zrはともに $\mathrm{p}$ 型のドーパントで, 占有するサイ 卜も異なる。Coは $\mathrm{A}_{1}$ と D サイトを占有して $\sigma$ 増加さ せ，Zrは DとEサイトを占有してSを増加させる(24)。 とSとの独立制御を試みるために，Co とZrをダブル・ド 一プした $\mathrm{Co}_{x} \mathrm{Zr}_{1-x} \mathrm{~B}_{105}$ 試料を作製して，電気物性を評価し た。その結果，Fig. 4 に示すよらに， $\sigma$ とSはCo 量によっ てはぼ決まり，Zrによるそれらの增加はわずかである。 $A_{1}$

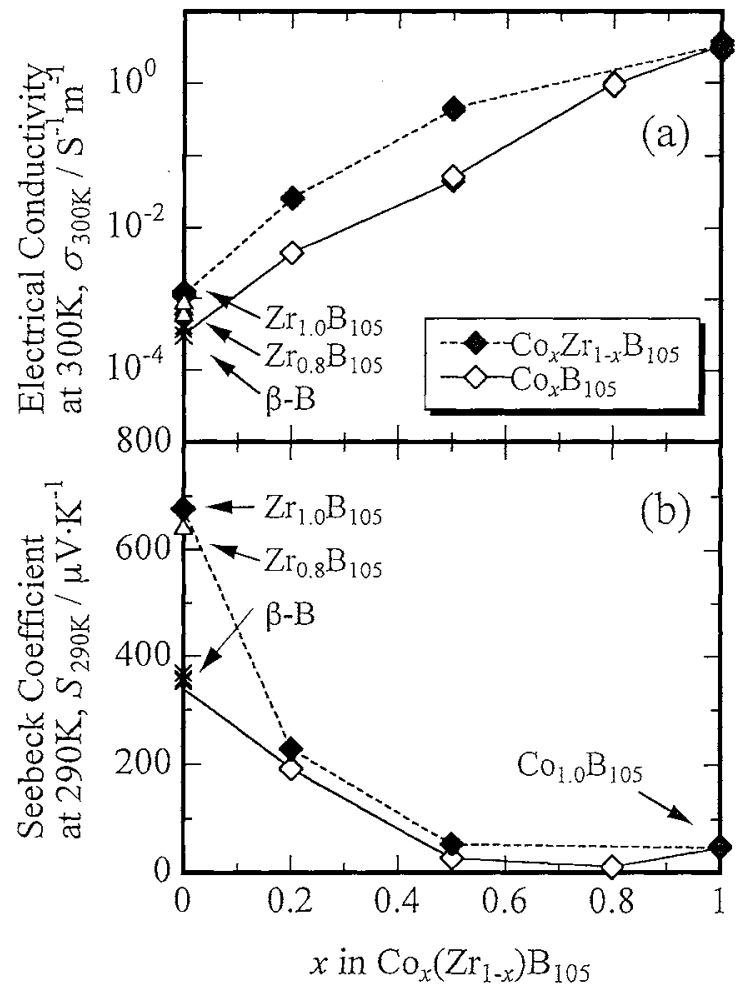

Fig. 4 Co concentration dependence of the electrical conductivity and the Seebeck coefficient for Co- and $\mathrm{Zr}$-doubly-doped $\beta$-rhombohedral boron. (a) The electrical conductivity at 300 $\mathrm{K}$, and (b) the Seebeck coefficient at $290 \mathrm{~K}$.

サイトを占有しているCoがボロンと混成して，局所的に金 属結合を誘起し，これが $N\left(E_{\mathrm{F}}\right)$ 飞強く影響しているためで あると考えられる。このように，現状ではまだ $\sigma$ と $S$ の独 立制御成功していないが， $x=0$ だけではなく $x=0.2,0.5$ の $\mathrm{Zr}$ 添加炕よっても， $\sigma$ と $S$ をともに増加させる傾向が見 られる.

\section{3. 電気伝導率とゼーベック係数の温度依存性}

$\beta$ ボロソ扣よび金属ドーピングした $\beta$ ボロンの電気伝導率 （ $\sigma ）$ 温度依存性をFig. 5 火示す。この温度依存性は，通 常の半導体の場合のアレニウス型や，ボロンカーバイドのフ オノン介助ホッピング型(28)

$$
\sigma=\frac{C}{T} \exp \left(-\frac{E}{k_{\mathrm{B}} T}\right)
$$

とは異なり，Mottの法則(29)

$$
\sigma=\sigma_{0} \exp \left\{-\left(\frac{T_{0}}{T}\right)^{1 / 4}\right\}
$$

に従ら可変領域ホッピング伝導的である。ここで, $C と \sigma_{0}$ は定数，Eは移動度の活性化エネルギー， $T_{0}$ はフェルミ。 レベルでのエネルギー状態密度 $N\left(E_{\mathrm{F}}\right)$ 亿逆比例する定数で ある.式(1)，（2）で表さ机るホッピング伝導では，キャリ アの数は温度変化しないが移動度が熱活性化型であるため, のは温度上昇とともに増加する. Mottの法則はアモルファ 


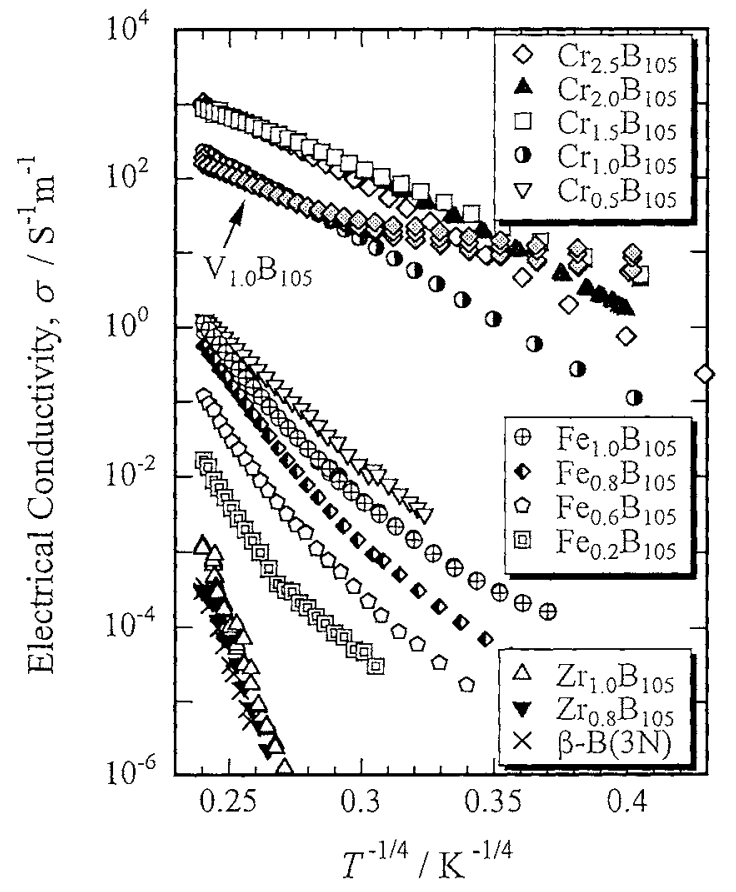

Fig. 5 Temperature dependence of the electrical conductivity for metal-doped $\beta$-rhombohedral boron.

スなどの乱机た采炕しばしば適用されるものであり，5回対 称性を有する $\mathrm{B}_{12}$ クラスターのネットワークから構成される $\beta$ ボロンは，構造と電気物性とるに乱れた系炕類似している と考学られる。ここで，Fig. 5 亿执いて特にVの場合は低 温で直線から外れる傾向が見られるが，これはX線回折で は確認できない㴽どの微量な $\mathrm{VB}_{2}$ 金属相が存在するためで あり，硝酸によってェッチングした試料で法低温季でMott 則に上く從う(25)。これらの微量金属相の影響は，温度依存 性が小さいため, 高温(室温付近)で母体ののが大きくなっ た温度領域では，無視することができる。のの温度依存性 (Fig. 5)の高温側の直線部分を式 (2)でフィッティングする ことによって $\sigma_{0}$ と $N\left(E_{\mathrm{F}}\right)$ を求めることがでさる． $\mathrm{A}_{1}$ サイ 卜を占有する $\mathrm{V}, \mathrm{Cr}, \mathrm{Co}, \mathrm{Fe}$ ドーピングについては，ドーピ ング量が增加しても $\sigma_{0}$ は添湾不变であるが， $N\left(E_{\mathrm{F}}\right)$ が急激 に增加 (Fig. 5 の傾き $\left(T_{0}\right)$ が減少)している。これは，2 節で 述べた V ドープの場合の光電子分光の結果 ${ }^{(13)}$ と一致してい る。一方， $\mathrm{A}_{1}$ サイト占有しない $\mathrm{Zr}$ ドープでは， $N\left(E_{\mathrm{F}}\right)$ は汪とんど増加していない。

乱れた系のゼーベック俰数(S)の温度依存性は，Wood と $\operatorname{Emin}^{(7)}$ 火よってスモール・ポーラロンのフォノン介助ホッ ピング伝導の場合の表式

$$
S=\left(T \Delta S^{\prime}+E_{\mathrm{T}}\right) / q T=A+B T
$$

が指摘されている、ここで $\Delta S^{\prime}$ はキャリアを注入した場合 のエントロピー変化, $E_{\mathrm{T}}$ は平均振動エネルギー, qはキャ リアの電荷, $A$ とBは定数を表す，可变領域ホッピング伝

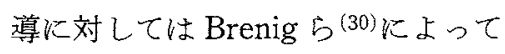

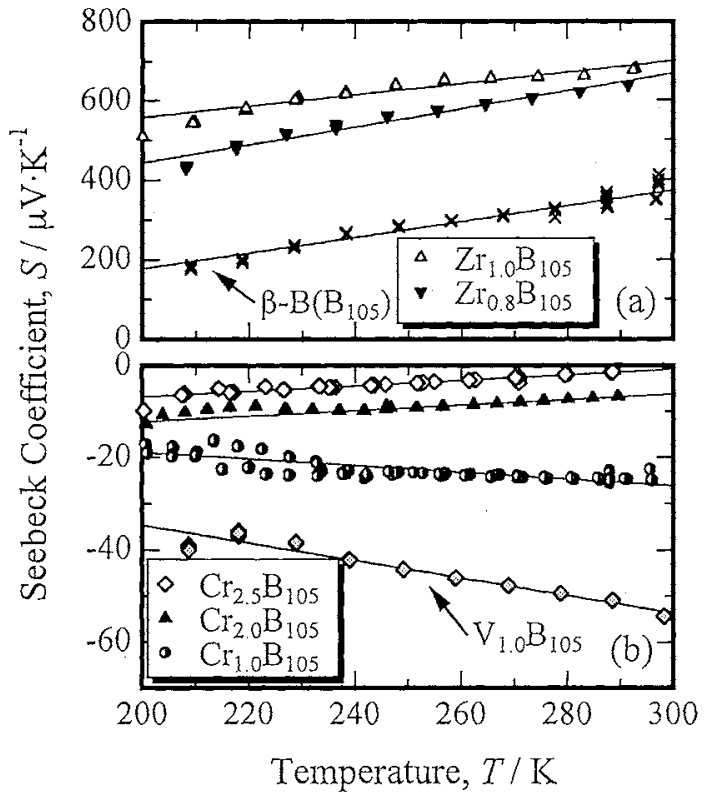

Fig. 6 Temperature dependence of the Seebeck coefficient for metal-doped $\beta$-rhombohedral boron.

$$
S \approx \frac{k_{\mathrm{B}}^{2}}{64 q} T_{0}^{1 / 2} T^{1 / 2}\left\{N^{\prime}(E) / N(E)\right\}_{E_{\mathrm{F}}}\left\{1+\left(T_{0} / T\right)^{1 / 4}\right\}
$$

といら温度依存性が，Overhof ${ }^{(31)}$ とってT五に比例する 温度依存性が提案されている。ここで $N^{\prime}(E)$ は $\partial N(E) / \partial E$ を表す。

$\beta$ ボロン拉よび $\mathrm{M}_{x} \mathrm{~B}_{105}$ の $\sigma$ は式 (2)で表される可变領域 ホッピング伝導型で説明できる. S の温度依存性は, Fig. 6 に示すように測定温度範团が狭いた如に, 式(4)で表され 当可変領域ホッピング型と式（３）で表されるフォノン介助 ホッピング型とを明膫汇別できないが，現状ではフォノン 介助ホッピング伝導的であると考兄ている. 広い、温度範用で の測定を行い，Sの表式を検証する他にも， $\sigma$ と $S$ 亿寄与す るキャリアが同一であるかも含めて，詳細を検討中である.

$\mathrm{C}_{x} \mathrm{Fe}_{1-x} \mathrm{~B}_{105}$ の 料 $\mathrm{M}_{x} \mathrm{~B}_{105}(\mathrm{M}=\mathrm{Cr}, \mathrm{Fe})$ の場合之同様に，可変領域ホッピン グ伝導型の温度依存性を示した。また $S$ は Fig. 7 亿示すよ 5に, $x=0.5$ の組成付近で, 低温では負の値を示すが高温 で正烧移し，電子とホールの両方が伝尊比寄与しているこ とを示唆する。皇礼ゆ兄電気伝導機構は $\mathrm{p}, \mathrm{n}$ 双方のキャリ アともにホッピング伝導である 2 バンド・モデルで理解で きるものと考完られる。

\section{4. 出力因子の温度依存性と組成依存性}

$\mathrm{M}_{x} \mathrm{~B}_{105}$ の出力因子 $(P)$ は, Fig. 8 亿示すように, 通常の 金属や半導体とは異なり，温度上昇によって $\sigma$ む $S$ も增加 するため，室温まで上昇し続ける、 $A_{1}$ サイトを占有するド 一ハンントでは $\sigma$ の增加が $S$ の減少を凌駕し， $x=0.8-1.5$ 付

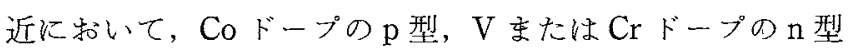




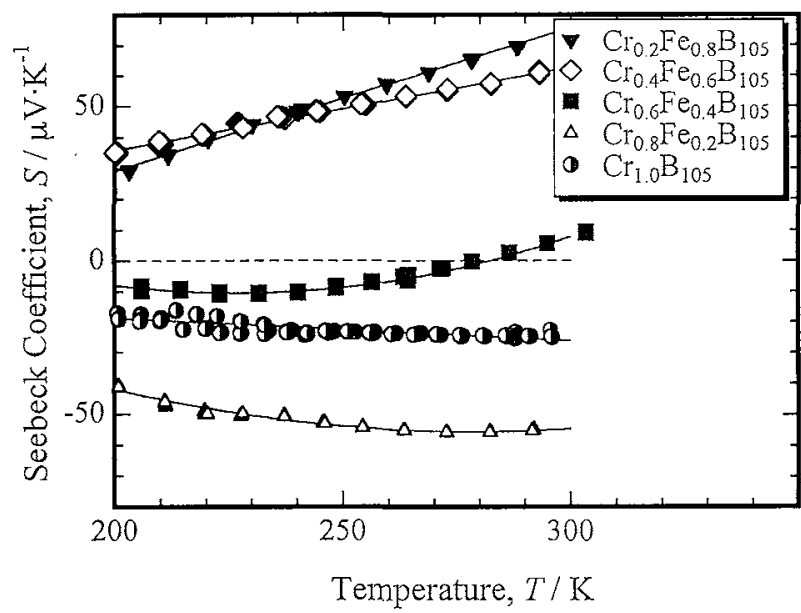

Fig. 7 Temperature dependence of the Seebeck coefficient for $\mathrm{Cr}$ - and $\mathrm{Fe}$-doubly-doped $\beta$-rhombohedral boron.

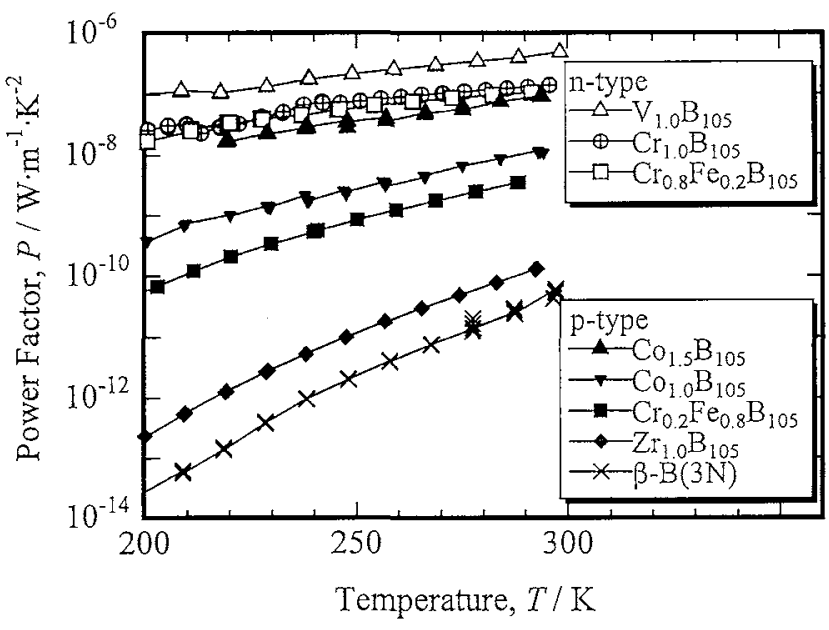

Fig. 8 Temperature dependence of the power factor of metal-doped $\beta$-rhombohedral boron.

の双方ともに， $\beta$ ボロンょりも $3 \sim 4$ 桁高い出力因子を示し た．室温以下の伝導機構が，高温でどこまで継続するかは調

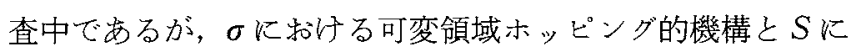
特けるフォノン介助ホッピング的機構が続く限り，Pは高温 でさらに上昇し続けるので，高温での更なる熱電特性の向上 が期待できる。

\section{N. 結 論}

$\beta$ 菱面体晶ボロン $\mathrm{B}_{105}$ 叔よび金属ドーピングした $\beta$ ボロ ソ $\mathrm{M}_{x} \mathrm{~B}_{105}(\mathrm{M}=\mathrm{V}, \mathrm{Cr}, \mathrm{Fe}, \mathrm{Co}, \mathrm{Zr})$ を作製 $\mathrm{L} ， そ の$ 電気伝導 率とぜ一ベック係数について，それぞれ組成依存性と温度依 存性を調べた。その結果，電気伝導率は $\mathrm{A}_{1}$ サイトの占有率 で制御することが可能である、V または $\mathrm{Cr}$ のように $\mathrm{A}_{1}$ サ イトを高く占有する元素では電気伝導率が著しく増加し, 負

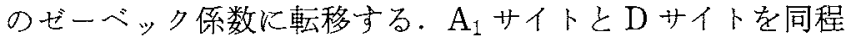

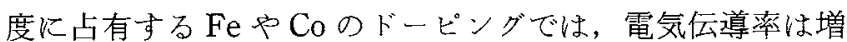
加するが，ゼーベック係数は正のまま減少する。逆に $\mathrm{A}_{1} サ$ イトを占有しない Z r では電気伝導率の増加はわずかである が，ゼーベック係数が增加する．DサイトまたはEサイト を占有するドーパントがゼーベック係数の増大に関与してい ると考学られる。

$\beta$ ボロンおよび $\mathrm{M}_{x} \mathrm{~B}_{105}$ の電気伝導率とゼーベック係数は 局在キャリアのホッピング伝導によって，温度上昇に伴って いずれる增加する。Coドープした $\mathrm{p}$ 型の $\beta$ ボロン，V は $\mathrm{Cr}$ ドープしたn型の $\beta$ ボロソいずれの出力因子も室温李 で上昇し続け，1 at \%程度の金属ドーピングによって，及ボ ロンの出力因子ょりも室温で $3 \sim 4$ 桁高い值を示した。

熱電材料およびゼーベック係数の測定法に関して貴重な助 言を頂き李した電子技術総合研究所の太田氏・山本氏に感謝 致します。本研究の一部は，池谷財団研究助成，文部省科学 研究費補助金によって行われた。

\section{文献}

(1) A. F. Ioffe: Semiconductor Thermoelements and Thermoelectric Cooling, Infosearch Ltd., London, (1956).

(2) D. M. Rowe and C. M. Bhandari: Modern Thermoelectrics, Reston Pub., Reston VA, (1983), pp. 15-33.

(3) H. J. Goldsmid: Electronic Refrigeration, Pion, London, (1986), pp. 12-41.

(4) 例光ば, I. Terasaki, Y. Sasago and K. Uchinokura: Phys. Rev., B56 (1997), R12685-R12687など.

(5) M. Fujimori, T. Nakata, T. Nakayama, E. Nishibori, K. Kimura, M. Takata and M. Sakata: Phys. Rev. Lett., 82(1999), 4452-4455.

(6) R. Franz and H. Werheit: AIP Conf. Proc., 231, AIP, New York, (1991), pp. 29-36.

( 7 ) C. Wood and D. Emin: Phys. Rev., B29(1984), 4582-4587.

(8) O. A. Golikova, V. K. Zaitsev, V. M. Orlov, A. V. Petrov, L. S Stilbans and E. N. Tkalenko: Phys. Stat. Sol., (a) 21(1974), 405.

(9) G. A. Slack, J. H. Rosolowski, C. Hejna, M. Garbauskas and J. K. Kasper: Proc. 9th Int. Symp. Boron, Borides and Related Compounds, Univ. of Duisburg, Duisburg, (1987), pp. 132141 .

(10) B. Pistourlet, J. L. Robert, J. M. Dusseau, J. M. Darolles, B. Armas and C. Combescure: Proc. Int. Solar Electric Conf., (1967), 887 .

(11) J. M. Darolles, T. Lepetre and J. M. Dusseau: Phys. Stat. Sol., (a) $58(1980), \mathrm{K} 71$.

(12) H. Nagai, S. Katsuyama, S. Nakayama, H. Kobayashi, K. Majima and M. Ito: Mater. Trans., JIM, 39 (1998), 515-521.

(13) K. Kimura, H. Matsuda, M. Fujimori, M. Terauchi, M. Tanaka, H. Kumigashira, N. Yokoya and T. Takahashi: Proc. 6th Int. Conf. on Quasicrystals, ed. by S. Takeuchi and T. Fujiwara, World Scientific, Singapore, (1998), 595-598.

(14) M. Fujimori and K. Kimura: J. Solid State Chem., 133 (1997), $310-313$.

(15) M. Fujimori and K. Kimura: Materia Japan, 37(1998), 606610.

(16) F. Izumi: The Rietveld Method, ed. by R. A. Young, Oxford University Press, New York, (1993).

(17) M. F. Gaubauskas, J. S. Kasper and G. A. Slack: J. Solid State Chem., 63 (1986), 424-430.

(18) S. Andersson and T. Lundström: J. Solid State Chem., 2(1970), 603-611.

(19) B. Callmer and T. Lundström: J. Solid State Chem., 17 (1976), 
165-170.

(20) B. Callmer and L. -E. Tergenius and J. O. Thomas: J. Solid State Chem., 26(1978), 275-279.

(21) D. Geist, R. Kloss and H. Follner: Acta Crystallogr., 26B (1970), 1800

(22) H. Matsuda, T. Nakayama, K. Kimura, Y. Murakami, H. Suematsu, M. Kobayashi and I. Higashi: Phys. Rev., 52(1995), 6102-6110.

(23) T. Lundström: AIP Conf. Proc., 140, AIP, New York, (1985), pp. 19-30.

(24) T. Nakayama, J. Shimizu and K. Kimura: in preperation, (1999).
(25) H. Matsuda, N. Tanaka, T. Nakayama, K. Kimura, Y. Murakami, H. Suematsu, M. Kobayashi and I. Higashi: J. Phys. Chem. Solids, 57(1996), 1167-1174.

(26) H. Matsuda and K. Kimura: Hyomen Kagaku, 18(1997), 156-164.

(27) M. Terauchi, Y. Kawamata, M. Tanaka, H. Matsuda and K. Kimura: J. Solid State Chem., 133(1997), 152-155.

(28) D. Emin and T. Holstein: Ann. Phys., 53 (1969), 439.

(29) N. F. Mott: Phil. Mag., 19(1965), 835-852.

(30) W. Brenig, G. H. Döhler and P. Wölfle: Z. Phys., 258(1973), $381-400$.

(31) H. Overhof: Phys. Stat. Sol., (b) 67(1975), 709-714. 